This PDF is a selection from a published volume from the National Bureau of Economic Research

Volume Title: Capitalizing China

Volume Author/Editor: Joseph P. H. Fan and Randall Morck, editors

Volume Publisher: University of Chicago Press

Volume ISBN: 0-226-23724-9; 978-0-226-23724-4 (cloth)

Volume URL: http://www.nber.org/books/morc10-1

Conference Date: December 15-16, 2009

Publication Date: November 2012

Chapter Title: Why Are Saving Rates So High in China?

Chapter Author(s): Dennis Tao Yang, Junsen Zhang, Shaojie Zhou

Chapter URL: http://www.nber.org/chapters/c12068

Chapter pages in book: (p. 249 - 278) 


\title{
Why Are Saving Rates So High in China?
}

\author{
Dennis Tao Yang, Junsen Zhang, and Shaojie Zhou
}

\subsection{Introduction}

The spectacular economic growth of China in the past three decades has been associated with an equally remarkable high rate of saving. While the gross national saving as a percentage of gross domestic product (GDP) hovered just a little above 35 percent in the 1980s, the average yearly rate climbed to 41 percent in the 1990s (figure 5.1). Since China's entry into the World Trade Organization (WTO), the growth in aggregate saving accelerated, surging from just below 38 percent in 2000 to an unprecedented 53 percent in 2007. China's national saving rates since 2000 have been one of the highest worldwide, far surpassing the rates prevailing in Japan, South Korea, and other East Asian economies during the years of their miracle growth. ${ }^{1}$

Dennis Tao Yang is professor of business administration at the University of Virginia. Junsen Zhang is the Wei Lun Professor of Economics at the Chinese University of Hong Kong. Shaojie Zhou is assistant professor in the School of Public Policy and Management at Tsinghua University.

The authors would like to thank Julan Du, Joseph Fan, Randall Morck, Leslie Young, and the participants in the NBER Conference on Capitalizing China in Boston, CUHK International Conference on China, and the Tsinghua Conference on Saving and Investment for their constructive comments and suggestions. The authors would also like to thank Jessie Pan for her excellent research assistance. The authors would like to acknowledge the financial support from the Research Grants Council of the Hong Kong Special Administrative Region, China (Project No. CUHK 453008), and the National Natural Science Foundation of China (Project No. 70903039), and the research support from the Hong Kong Institute of Asia-Pacific Studies. Dennis T. Yang acknowledges the research support provided by the Hong Kong Institute of Monetary Research, where he conducted research when he served as a research fellow. For acknowledgments, sources of research support, and disclosure of the authors' material financial relationships, if any, please see http://www.nber.org/chapters/c12068.ack.

1. These saving figures are based on information from the World Development Indicators (WDI). In 2008, the gross national saving rate of China ranked the ninth-highest among 228 
The high and rising aggregate saving and thus the low and declining share of consumption in the GDP constitute a central feature of the Chinese economy. High saving is not only closely related to domestic liquidity, investment, economic growth, and income distributions among firms, households, and the government but also to China's international trade and capital flows. With the government's concerted efforts to stimulate consumption and economic growth amid the recent financial crisis, increasing attention has been given on the issue of saving. Despite the bourgeoning literature on the subject, debates continue among economists regarding the underlying causes of China's high rate of saving. Although some progress has been made to understand household saving behaviors, a significant void in research on corporate and government saving still remains. The main objectives of this chapter are to document historical trends in Chinese aggregate saving using multiple data sources, analyze the forces that contributed to the recent rise in government, corporate, and household saving, and assess the prospects for Chinese national savings in the near future.

We start with an overview of the major patterns in Chinese national saving in the past three decades. Drawing data from the World Development Indicators (WDI), China's Flow of Funds Accounts (FFA), and other sources of aggregate statistics, we analyze and compare the aggregate saving in China with that of representative economies and major country groups. A breakdown of aggregate saving into the components of corporate, household, and government reveals major changes and sources of national saving over time. These analyses help define "The Chinese Saving Puzzle," a set of unique features still not well understood in the existing literature of aggregate saving in the historical context of China and in light of international comparisons.

We then proceed to examine the sources and causes of the rising saving of the government, corporate, and household sectors in China, focusing on the period of 1999 to 2007. The sharp rise in government taxes on production and the collection of social security fees and income taxes were the dominant factors that increased the disposable income of the government. As the growth of income outpaced that of government consumption, the saving rate rose rapidly. The analysis of enterprise behavior opens the discussion on data-related issues pertaining to the FFA, the main source of data for documenting aggregate saving in China. We examine the role of firm profitability, labor compensation and dividend, imperfect capital markets, and government policies in shaping corporate saving. Our analysis of household behavior relies on data from the Urban Household Survey (UHS) from six provinces, covering the period of 1992 to 2006 . We summarize stylized facts

countries recorded in the WDI database. The eight economies with higher saving rates than China are all very small. Saudi Arabia and Singapore are the two economies of significant size with saving rates below that of China, but were nonetheless above 50 percent. 
on household saving and explore the factors we believe have driven the recent upward trend in household saving. The role played by unique institutions, policies, and reform processes in China is assessed.

Lastly, based on the foregoing analysis of saving determinants, we argue that systematic forces, such as slower economic growth, moderate export expansion, and government plans to strengthen social welfare and population aging, are already set in to induce a decline in aggregate saving. A saving rate of above 50 percent of the GDP could already be a phenomenon of the past, and China would likely enter an era of a more balanced growth.

\subsection{Long-Term Trends in Aggregate Saving}

\subsubsection{International Comparison}

To document the special features of Chinese saving in light of international experience, we make a cross-country comparison of national saving rates using the WDI (World Bank 2010b). The WDI defines gross domestic saving as GDP less the aggregate consumption expenditures based on data from national income accounts. Using this standard definition, we compare China's saving rates for the period of 1978 to 2008 with those of countries from different income groups, BRIC economies (Brazil, Russia, India, and China), and selected developed economies.

Figure 5.1, part A, shows that the rate of aggregate saving in China has remained persistently above 34 percent of the GDP since 1978, the year when systematic economic reforms began. Therefore, high saving in China has been a long-term phenomenon. Since 2000, there has been a surge in the saving rate, reaching a startling 53.1 percent of the GDP in 2007. The saving rates of middle-income and low-income groups have also increased, but at a rate much slower than that of China. In 2006, the latest year with available data on the saving rates of all country groups, the saving rate of China (52.4 percent) was about 3.3 times higher than that of the low-income group (16.1 percent), and 2.4 times higher than the world average (22.1 percent).

China's high saving also stands out among those of the BRIC economies, as shown in part B of figure 5.1. In 2008, the national saving rate in China was 49.2 percent, whereas the rate for Russia was 36.3 percent, India 32.9 percent, and Brazil 19.1 percent. Despite two erratic spikes in Russia's saving series, there has been a recent upward trend in saving for all three countries. Between 1998 and 2008, the saving rate of Brazil increased by 4.1 percentage points, Russia by 14.6 percentage points, and India by 11.9 percentage points.

In contrast to the rising saving observed in the large and fast-growing developing countries, the overall saving rates of industrialized economies have experienced a gradual decline, as seen in figure 5.1, part C. In the early 1990s, the level of saving in China was comparable with that of its rich East 

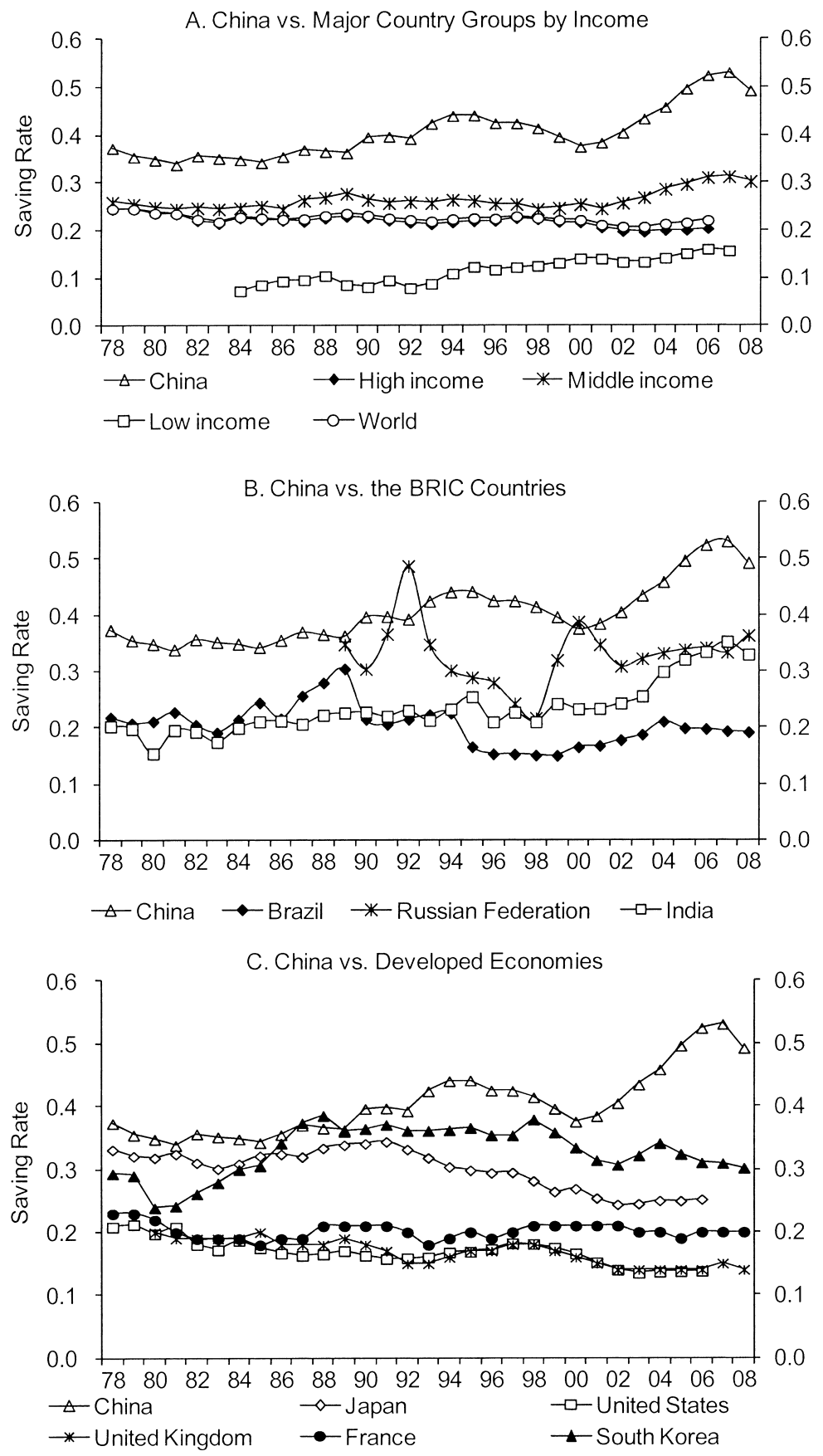

Fig. 5.1 Gross national saving rates of China and other economies, 1978-2008 Source: World Development Indictors (World Bank 2009). 
Asian neighbors, Japan and South Korea. However, the saving rate of Japan continually declined after reaching a peak of 34.4 percent in 1991 until it dropped to a three-decade low of 25.2 percent in 2006. The saving rates of the United States, France, and the United Kingdom have either stagnated or experienced chronic decline in the past three decades. Since 2000, the disparity in gross domestic saving rates between China and the major developed countries has widened. By 2006, the saving rate of China was 27.2 percentage points higher than that of Japan and 38.6 percentage points higher than that of the United States. By 2007, the gap in gross saving between China and South Korea grew to 22.1 percentage points, whereas the gaps in France and the United Kingdom increased to 29 and 35 percentage points, respectively.

\subsubsection{Components of Aggregate Saving}

The high and rising aggregate saving in China can be analyzed by source through the three components: households, enterprises, and the government. Earlier studies that analyzed by sector saving include Qian (1988) for the period of 1978 to 1984, Kraay (2000) for 1978 to 1995, Kuijs (2005, 2006) for 1990 to 2005, and Chamon and Prasad (2010) for 1990 to 2005.

At the inception of reforms in China in 1978, total household saving only accounted for 6 to 7 percent of the GDP, whereas the government saving hovered around 15 to 18 percent of the GDP (Qian 1988; Kraay 2000). Between 1978 and 1984, the household saving continued to rise, and the government saving fell dramatically, maintaining the aggregate saving rate at a stable level. The decline in government savings persisted through the early 1990s.

In 1995, the National Bureau of Statistics (NBS) began to publish the FFA based on the physical transitions of the national income accounting in the Statistical Yearbook of China. With a three-year lag policy, the most recent data available for this chapter cover the period of 1992 to $2007 .^{2}$ Whereas the WDI data cover a much longer period, the FFA data have the advantage of reporting the composition of gross domestic saving by household, business, and government, as well as information on incomes and expenditures within each of the sectors. Figure 5.2 presents three interesting observations. ${ }^{3}$ First, aggregate saving in China remained at a high level of

2. See He and Cao (2007) and Ma and Wang (2010) for the analyses of Chinese aggregate saving using the FFA data.

3. Yearly saving rates based on the FFA data have noticeable differences from the rates based on the WDI data as reported in figure 5.1, although the long-term trends are generally consistent. Comparing these two data series, we find that from 1992 to 1999, the WDI measure was 2.8 to 6 percentage points higher than the FFA measure. In 1999, their difference amounted to 5 percentage points. Since 2000, however, the difference has become much smaller, except for 2006 when the FFA measure exceeded the WDI measure by 2.9 percentage points. Note that these two measures of domestic saving rates have the same definition - that is, 1 - final consumption expenditure/GDP - and the final consumption includes household consumption and general government consumption expenditures. Although there is little difference in the ratio of government consumption to the GDP in the two data sets, the FFA data report a higher 


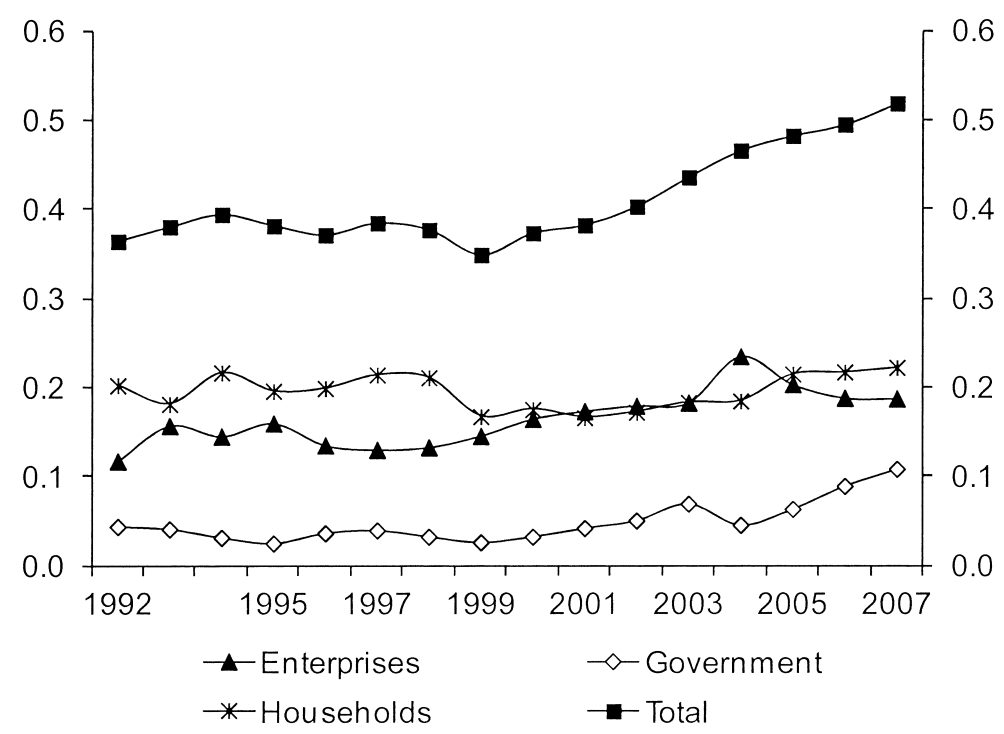

Fig. 5.2 Household, enterprise, and government saving as percentage of GDP, 1992-2007

Source: NBS (1995-2009).

above 34.9 percent of the GDP for the entire period. Second, there was a recent surge in saving rate by almost 17 percent from 1999 to 2007. Finally, all three sectors contributed significantly to the upsurge of the gross national saving. Between 1999 and 2007, the share of corporate saving rose from 14.6 to 18.8 percent of the GDP, the household saving from 16.7 to 22.2 percent, and the government from 2.6 to 10.8 percent. Overall, the largest percentage increase, by 8.2 percent of the GDP, was the saving of the government.

\subsubsection{The Chinese Saving Puzzle}

In light of the historical trends and international comparisons, we consider the Chinese saving puzzle to have four interrelated aspects: (a) persistently high saving rates between 34 and 53 percent of the GDP in the past thirty years; (b) an outlier in international comparisons, that is, having one of the highest saving rates among all nations since 2000, and an outlier

ratio of household consumption to GDP, especially for the periods 1992 to 1999 and 2005 to 2006. Therefore, the disparity in domestic saving rates comes mainly from the differences in household consumption expenditures to the GDP. This disparity reflects in part the content of household consumption in the two data sets. According to FFA statistics, household final consumption expenditure includes not only monetary spending but also in-kind consumption, which could result in higher ratios of household consumption to GDP in the FFA data. In addition, the WDI measure of the final consumption in the GDP also includes any statistical discrepancy in the use of resources relative to the supply of resources, which could contribute to the disparity in domestic saving rates between FFA and WDI data. 
in cross-country regressions of saving determination; ${ }^{4}$ (c) surge in gross domestic saving by 11 percentage points between 2000 and 2008 based on the WDI data; ${ }^{5}$ and (d) household saving as a share of GDP experiencing the highest growth among the three sectors since the inception of reforms in $1978 .{ }^{6}$ These observations jointly define the Chinese saving puzzle. We consider it a puzzle because the fundamental forces shaping these special saving patterns are still not well understood.

In what follows, we use the FFA data to investigate the sources and causes of the high and rising government and corporate saving in the period of 1992 to 2007 and use UHS data to examine household saving in the period of 1988 to 2007 . The time coverage reflects data availability.

\subsection{Corporate Saving}

The high corporate and government saving during the earlier years of reform reflects the high-investment and heavy industry-oriented development strategy adopted in the central planning period. Between 1965 and 1977, the gross national saving of China averaged 27 percent of the GDP and had a small component of household saving (Kraay 2000). As the state influence of enterprise accumulation diminished with the introduction of reforms, aggregate corporate saving declined to only about 13 percent of the GDP in the late 1990s. What forces drove up corporate saving by about 6 percentage points of the GDP in the period of 1999 to 2007 ?

The trend of rising enterprise saving is most commonly documented using the FFA data from the national income accounts of China. ${ }^{7}$ As defined by FFA, enterprise saving equals the value-added of both financial and nonfinancial companies minus labor compensation, production taxes, net asset payments, and net transfer payments. ${ }^{8}$ In China, total enterprise saving is equivalent to the "total disposable income" of the business sectors, but the concept is different from either net income or free cash flow in the standard corporate finance literature. It is a concept very close to net income plus

4. Kraay (2000) uses a large sample of countries to investigate the cross-country determinants of saving and finds that economy-wide saving in China is nearly 10 percentage points higher than what would be expected based on standard determinants of national savings.

5. Note that the FFA data reveal a generally consistent trend, although its data coverage ends in 2007.

6. According to Qian (1988) and Kraay (2000), household saving accounted for only 6 to 7 percent of the GDP in the late 1970s. As figure 5.2 shows, however, household saving as a share of the GDP climbed to 22.2 percent in 2007, implying an increase of about 16 percent. In contrast, the combined savings by the government and enterprises stayed roughly the same at about 30 percent of the GDP in the beginning and ending years of the analysis.

7. An exception is Bayoumi, Tong, and Wei (chapter 6, this volume), who examine Chinese corporate saving behavior based on firm level data.

8. More specifically, asset payments include interest payments, dividends, and land rentals, whereas transfers include corporate income tax, social insurance fees, social subsidies, and social welfare payments. 
depreciation and amortization. Thus, the formation of fixed capital, capital transfers, changes in inventory, and equity investments are not included in the calculation of enterprise saving.

Using this definition of corporate saving in Chinese statistics, the legacy of the high-accumulation strategy from the central planning and incomplete institutional reforms can partially explain the high enterprise saving in the past three decades. For instance, the suppression of wages, low-interest payments on loans, and low land rentals all tended to raise the disposable income of the enterprises, thus giving them more opportunities to save. ${ }^{9}$ These forces of economic planning continued into the reform era despite a gradual decline in the magnitude of the distortions over time. However, aside from these institutional factors that influence the general level of business saving, we argue that several factors have helped elevate enterprise saving in the past decade.

\subsubsection{Rising Profitability of Enterprises}

The saving capacity of enterprises reflects their profitability. As shown in figure 5.3, the profitability of enterprises has generally improved since the early 1990s. While the nominal firm profits increased more than fifteenfold from 1992 to 2007, the ratio of profits to industrial value added also improved remarkably, from about 21 percent in the late 1990s to close to 30 percent in 2007. Figure 5.4 provides corroborative evidence that the share of enterprise income in the GDP rose from 13 percent in the late 1990s to above 18 percent in 2007.

The rise in corporate profitability is an outcome of a series of socioeconomic and institutional changes implemented in China throughout the reform period. For instance, the privatization of state-owned enterprises (SOEs) and the growth of private enterprises are found to have induced more innovative efforts and raised the labor and total factor productivity of the corporate sector (Jefferson and Su 2006; Bai, Lu, and Tao 2009). Labor market reforms involving the use of labor-incentive schemes, the relaxation of worker mobility restrictions, and especially the massive ruralurban migration have all contributed to the efficient functioning of firms. In particular, the large flow of rural labor to cities, which was estimated at around 135 million in 2007 (Meng et al. 2010), has helped maintain low labor costs for business, a major factor behind China's emergence as the workshop of the world (Yang, Chen, and Monarch 2010). Moreover, China began implementing a large-scale privatization of SOEs in 1998 with the objectives of improving corporate governance and maintaining the competitiveness of the state sector in the national economy. From 1997 to 2003, the share of SOE workers in urban employment dropped from 54.6 to 26.8 percent as the

9. We are grateful to Leslie Young for making constructive suggestions on these arguments as well as referring us to the related literature. 


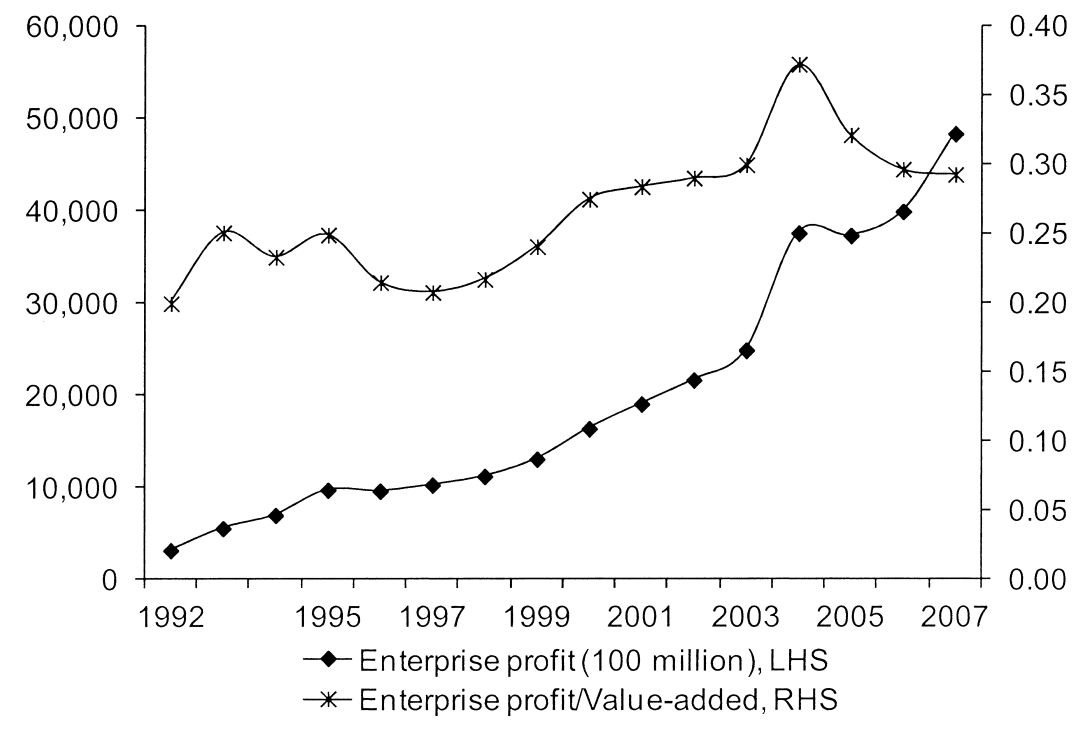

Fig. 5.3 Enterprise profit and value added, 1992-2007

Source: NBS (1995-2009).

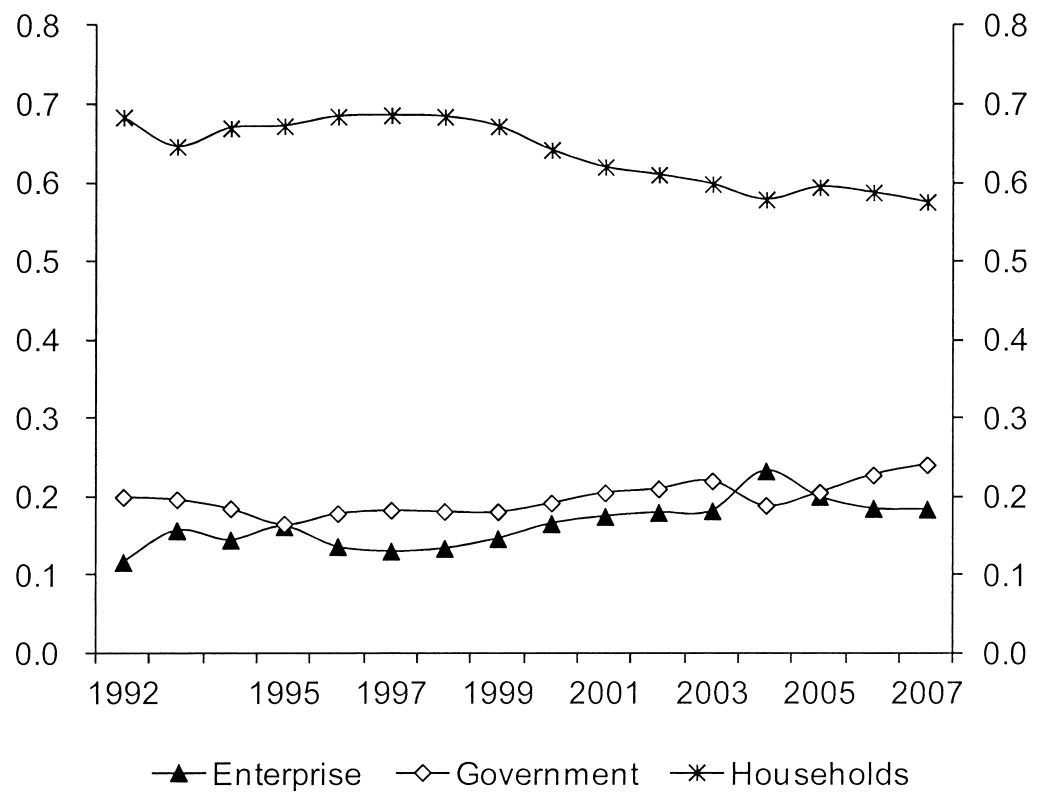

Fig. 5.4 Income distribution among households, enterprises, and government, 1992-2007

Source: NBS (1995-2009). 
result of enterprise restructuring (National Bureau of Statistics of China, NBS 1998, 2004). The productivity of the state sector rose, and the competitive pressure also spread to raise the productivity of the nonstate sector.

The rise in corporate saving - that is, 14.6 to 18.8 percent of the GDP from 1999 to 2007 - was also attributable to China's remarkable expansion in export associated with its accession to the WTO. Beginning in the late 1990s, with the anticipation of joining the WTO, China's export growth accelerated. The momentum of trade expansion continued after China's accession to the WTO in 2001 as trade barriers and tariffs continued to fall. Between 1999 and 2007, the export growth reached an unprecedented 26 percent per annum (NBS 2008). This expansion in external demand handed China an opportunity to realize its potential comparative advantage in trade. When exports were combined with equally remarkable foreign direct investment (FDI) inflows as well as the imports of sophisticated intermediate inputs, these factors jointly created a powerful force to increase firm productivity and profits.

Trade expansion, and thus increases in corporate revenue, was facilitated by trade policies in China. Since 1998, after the Asian financial crisis, China has initiated a trade-promoting policy of rewarding tax rebates for exports (TRE). Since then, TRE has become an important macroeconomic management policy. The value of the rebate increased substantially after China's accession to the WTO. Figure 5.5 shows that the total volume of TRE increased from 115 billion Yuan in 2002 to 586.6 billion in 2008. The size of these tax rebates was highly significant: in 2006, the total TRE received by exporting firms was equivalent to 10 percent of aggregate corporate saving and about 14 percent of government tax revenue in the same year. The TRE remained at high levels throughout 2004 to 2008 . Therefore, the expanded external demand and favorable trade policies both helped raise the corporate earnings of Chinese firms with the accession of China to the WTO.

\subsubsection{Costs of Financing, Dividend Payments, and Labor Compensations}

While export expansion and tax rebate added directly to the revenue of firms, maintaining the low cost of production also contributed to the rise in the disposable incomes of enterprises. Ma and Wang (2010) find that net interest payments as share of the GDP by the nonfinancial corporate sector dropped by 50 percent between 1992 and 2007. In particular, SOEs financed their loans and paid their debts at interest rates much lower than the prevailing market rates. If SOEs actually paid at market interest rates, their existing profits, and thus their saving, would have been greatly reduced (Ferri and Liu 2009). Moreover, enterprises managed to control labor compensation during the same period. As shown in figure 5.6, the share of labor compensation of employees in the total value added of enterprises declined from 


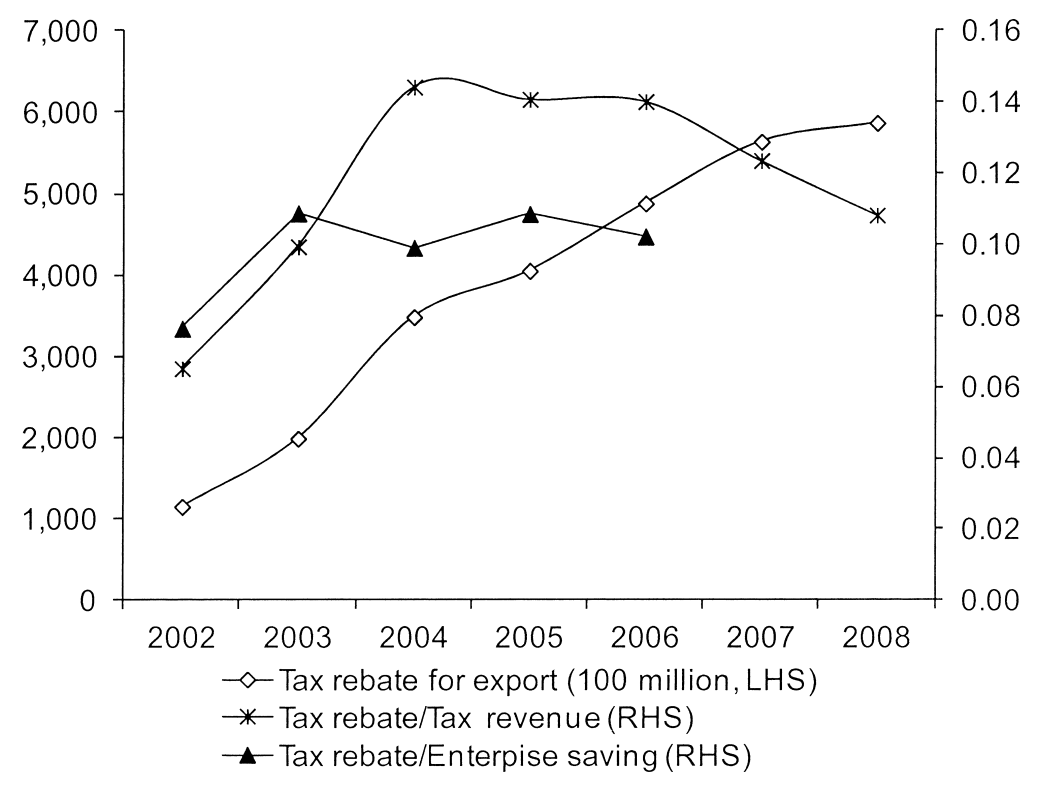

Fig. 5.5 Tax rebate for export in China, 2002-2008

Source: NBS (2003-2009).

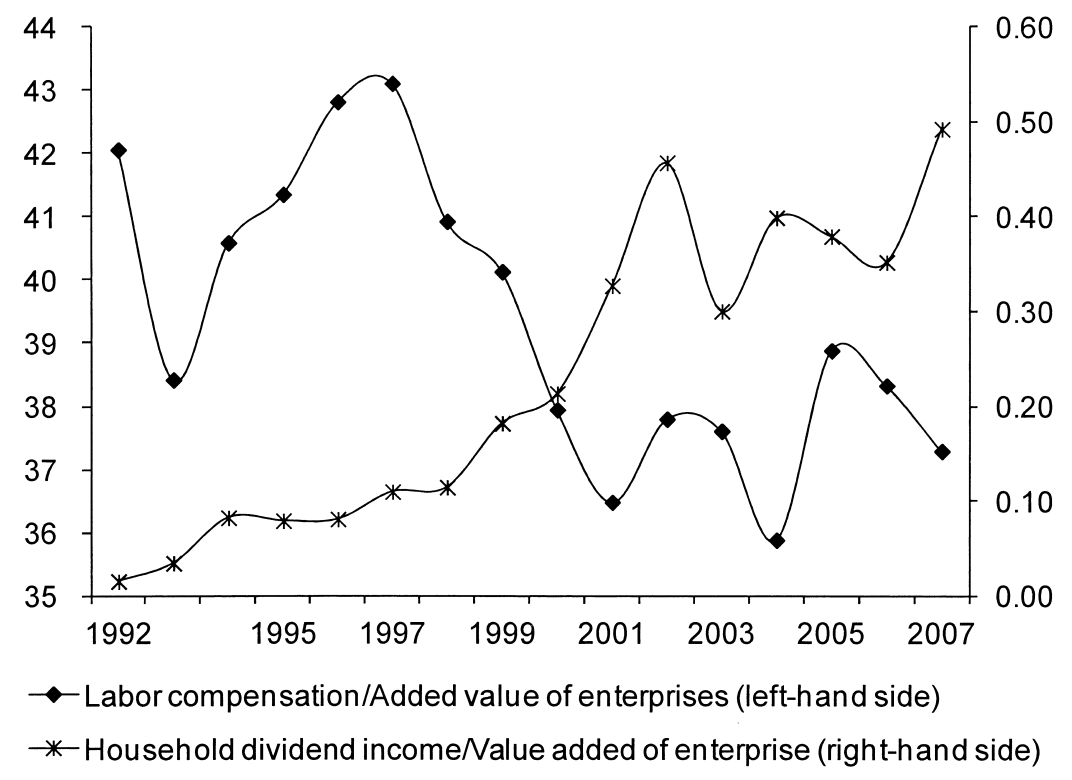

Fig. 5.6 Labor compensation and dividend distributed to households, 1992-2007 Source: NBS (1995-2009). 
an average of 41.2 percent in the 1990 s to 37.5 percent in the 2000 s, helping raise the enterprise saving capacity. Although some stockholders earn dividends, total dividend payments only accounted for a small proportion of the enterprise value added. Despite an upward trend in dividend payments, the ratio of dividend to value added was still less than 0.5 percent by 2007 (figure 5.6). Part of the story is that the Chinese government did not ask SOEs to pay dividends until 2008 even though they had enjoyed improved profits since the state-sector restructuring in the late 1990s. These aggregate statistics appear to be consistent with firm-level data reported in Zhang (2008) that for a large sample of Chinese firms in the period of 1999 to 2003, the average and median dividends to earnings ratios were 0.35 and 0.16 , respectively. Lower dividends translate directly to more retained corporate earnings based on the FFA statistics.

\subsubsection{Imperfect Capital Markets}

Weaknesses in China's financial sector motivated the enterprises, especially small and medium-sized enterprises (SMEs), to rely on their own saving to finance fixed-asset investments. Despite the systematic financial reforms since the middle 1990 s, including the reconstruction of nonperformance loans, banks in China still play a limited role in channeling saving from frugal households to the enterprise sector (e.g., Hofman and Kuijs 2006).

Table 5.1 reports the sources of funding for fixed-asset investments in the period of 1995 to 2007 . Contrary to the conventional wisdom that bank credits are the main source of financing, the share of domestic loans remained below 21 percent of the total investments throughout the period. Instead,

Table $5.1 \quad$ Sources of funds for fixed assets investment (\%)

\begin{tabular}{cccccc}
\hline Year & State budget & Domestic loans & FDI & Self-raising funds & Others \\
\hline 1995 & 3.03 & 20.46 & 11.19 & 51.88 & 13.45 \\
1996 & 2.68 & 19.58 & 11.76 & 47.74 & 18.24 \\
1997 & 2.76 & 18.93 & 10.63 & 49.71 & 17.97 \\
1998 & 4.17 & 19.30 & 9.11 & 48.81 & 18.61 \\
1999 & 6.22 & 19.24 & 6.74 & 49.20 & 18.59 \\
2000 & 6.37 & 20.32 & 5.12 & 49.28 & 18.91 \\
2001 & 6.70 & 19.06 & 4.56 & 49.79 & 19.89 \\
2002 & 7.02 & 19.67 & 4.63 & 50.65 & 18.04 \\
2003 & 4.59 & 20.55 & 4.43 & 53.65 & 16.78 \\
2004 & 4.37 & 18.49 & 4.41 & 55.35 & 17.39 \\
2005 & 4.39 & 17.25 & 4.21 & 58.26 & 15.89 \\
2006 & 3.93 & 16.47 & 3.64 & 59.75 & 16.21 \\
2007 & 3.88 & 15.28 & 3.40 & 60.59 & 16.84 \\
2008 & 4.35 & 14.46 & 2.90 & 64.79 & 13.50 \\
\hline
\end{tabular}

Source: China Statistical Yearbook 2009. 
self-raised funds always accounted for the largest share of contribution to investment. It is worth pointing out that the share of self-raised funds in the total investment increased over time, rising from just below 50 percent in the middle 1990s to 64.8 percent in 2008. In other words, enterprise investment relied more on self-retained earnings, whereas the importance of domestic loans generally declined in the last decade. Therefore, the high saving of enterprises, particularly among SMEs, can be interpreted as reflecting the difficulties in obtaining financing from state banks because of the lack of collaterals required to secure loans.

By 2008, the state budget and FDI contributed to about 7 percent of the total fixed-asset investment. Informal and private financing channels, as represented by the "others" category, accounted for 13.5 percent of the total financing; this share is comparable in size with domestic loans. Therefore, despite the development and commercialization of capital markets in China, formal financing through bank loans is still limited. The weak financial sector creates the incentives for enterprise saving.

\subsection{Government Saving}

Government in the FFA data refers to all levels of administrative units and nonprofit institutions affiliated with the state and local governments. Table 5.2 presents the data series on consumption, saving, and detailed components of government disposable income. The figures are expressed in nominal terms because selecting price deflators for different variables is prone to arbitrariness, and our primary interest is the changes in yearly saving rates based on current prices. The share of government saving in GDP fluctuated at a level below 4.4 percent in the period of 1992 to 1999, reaching the lowest point at 2.6 percent in 1999. However, the figure had climbed since then, reaching 10.8 percent in 2007.

The government's disposable income, which mainly consists of value added from government production, incomes from properties, taxes on all production, income taxes, and social insurance revenue but minus labor compensations, rose from 1,608.9 billion Yuan in 1999 to 6,308.4 billion Yuan in 2007, as indicated in column (6) of table 5.1. The rise in tax revenues on production, as reported in column (3), was the largest contributor to the growth in government income during this period. The net tax increased by 3058.5 billion Yuan, accounting for 65 percent of the increase in the disposable income of government. The institutional foundation behind the rise in tax revenues can be traced back to the famous 1994 Fiscal Reform in China that managed to reverse a declining trend in state revenues beginning in the mid-1980s. The reform aimed to boost revenue collections and reclaim the majority of the total revenue by the central government (Bahl 1999; Wong and Bird 2008). From having a low share of net revenue in the GDP in the earlier 1990s, the effective tax system, when combined with an 


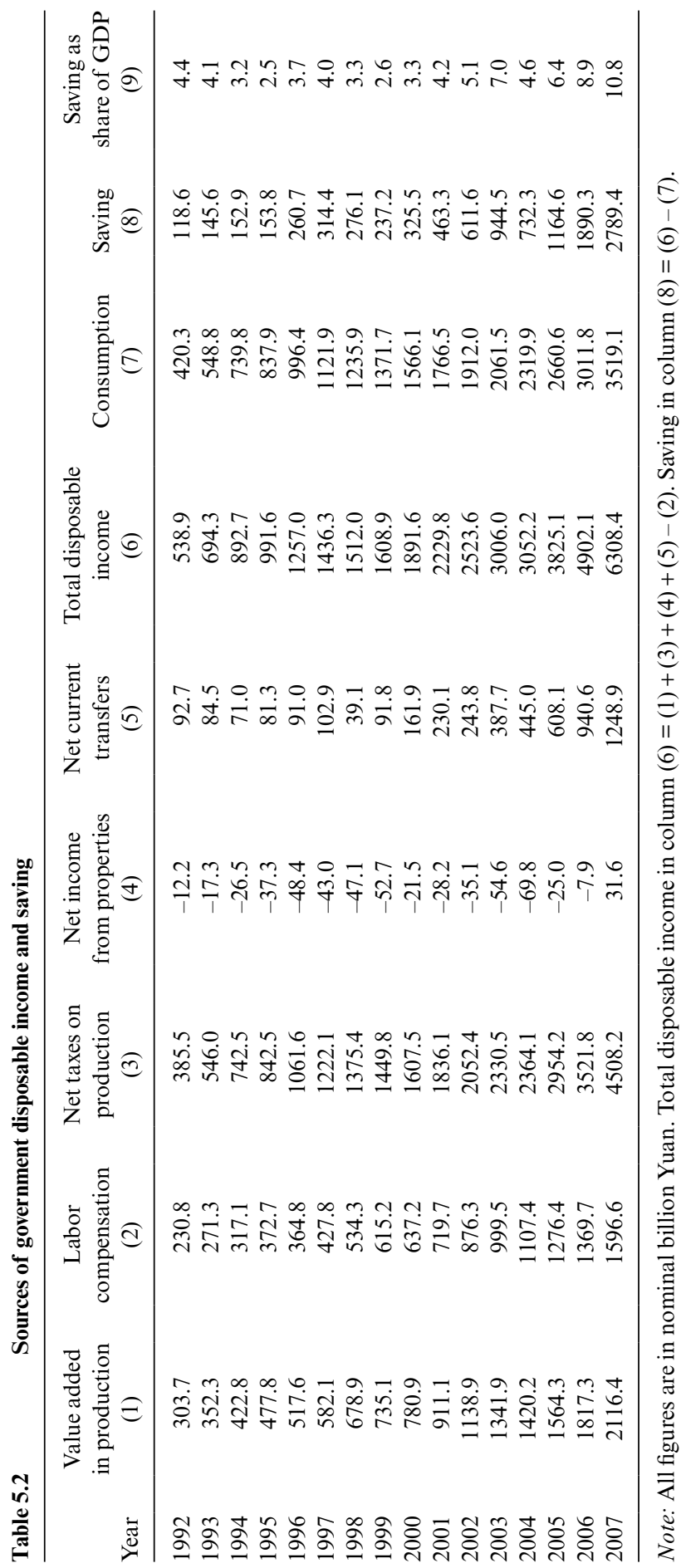


average annual GDP growth of about 10 percent, resulted in continued rise in government revenue from 1999 to 2007.

The second largest contributing factor to government disposable income is net current transfers. According to more detailed FFA sources not reported in table 5.1, the government collected 1,195.5 billion Yuan of income taxes and 1,081.2 billion Yuan of social insurance fees in 2007, but only spent 1,028 billion Yuan on social welfare payments, social insurance provisions, and other transfers. As a result, the government had a net gain of 1,248.9 billion Yuan in net transfers in 2007, which is an increase of 1,157.1 billion Yuan from the 1992 level, accounting for 25 percent of the growth in government disposable income during the same period. Overall, the combined increase in taxes on production and transfers added to about 90 percent of the growth in disposable income from 1992 to 2007.

Compared with the sharp increase in state income, the total growth of 2,147.4 billion Yuan in consumption is still modest. As a result, government saving increased by $2,147.4$ billion Yuan, translating to an 8.2 percentagepoint increase in its share in the GDP. This tally is consistent with the popular view of "Nation Rich, People Poor," which is now widely discussed in the public media in China. A piece of corroborative evidence is that the share of household income in the GDP declined from 68.6 percent in 1996 to 57.5 percent in 2007 (figure 5.4). Although this view correctly describes the changes in income positions of the government in the past two decades, China's tax revenue as a percentage of the GDP is still lower than that of major developed economies, such as Japan, Germany, and the United States.

\subsection{Household Saving}

Household saving in China rose substantially in the past three decades along with economic reforms and fast income growth. As noted earlier, household saving only accounted for 6 to 7 percent of the GDP in the late 1970s but grew to about 22 percent in 2007 based on the FFA data (figure 5.2). In what follows, we use more detailed UHS data to document the major features of the Chinese household saving in the period of 1988 to 2007. In light of these stylized facts, we provide a critical overview of the existing literature and present our views on the main factors behind the rise in household saving in China.

\subsubsection{Data and Stylized Facts}

The data we use come from twenty consecutive years of the UHS conducted by China's NBS. The computer usable form of data began in 1988; the latest data are from 2007 due to the NBS one-year-lag policy for releasing household surveys. The UHS data record basic conditions of urban households and detailed information on income, employment, demographic characteristics of all household members, and detailed consumption infor- 
mation in each calendar year. Our sample comes from five large provinces (i.e., Liaoning, Zhejiang, Guangdong, Sichuan, and Shannxi) and one municipality (i.e., Beijing). These provinces are representatives of China both in terms of income dispersions and geographical coverage.

Household saving is computed as the difference between disposable income and consumption expenditures on food, clothing, housing services, transportation, communication, entertainment, education, medical care, and other miscellaneous items. We also make use of demographic variables, such as young dependency (i.e., the ratio of children below sixteen to adults aged between sixteen and fifty-five for women and sixty for men) and old dependency (i.e., the ratio of the elderly above fifty-five for women and above sixty for men to the working age population), to determine whether saving varies with demographic structures. We limit our analysis to households whose heads are aged between twenty-five and seventy, and exclude self-employed families due to difficulties in computing family incomes.

Table 5.3 reports the basic summary of statistics on the urban household sample. The average household income grew from 14,918 Yuan in 1988 to 49,061 Yuan in 2007, increasing by more than threefold during the twentyyear period. Likewise, the average household consumption increased substantially, although at a rate slower than income growth. As a result, the rate

Table 5.3

Summary statistics of the urban household sample, 1988-2007

\begin{tabular}{ccccc}
\hline Year & $\begin{array}{c}\text { No. of } \\
\text { observations }\end{array}$ & $\begin{array}{c}\text { Income } \\
(2007 \text { yuan })\end{array}$ & $\begin{array}{c}\text { Consumption } \\
(2007 \text { yuan })\end{array}$ & $\begin{array}{c}\text { Saving rate } \\
(\%)\end{array}$ \\
\hline 1988 & 2,869 & 14,918 & 14,083 & 5.6 \\
1989 & 2,683 & 14,521 & 12,905 & 11.1 \\
1990 & 2,977 & 15,456 & 13,093 & 15.3 \\
1991 & 2,998 & 16,453 & 14,178 & 13.8 \\
1992 & 3,673 & 18,904 & 15,885 & 16.0 \\
1993 & 3,698 & 20,208 & 16,973 & 16.0 \\
1994 & 3,713 & 22,308 & 18,584 & 16.7 \\
1995 & 3,727 & 22,914 & 19,212 & 16.2 \\
1996 & 3,717 & 23,651 & 19,473 & 17.7 \\
1997 & 3,704 & 24,472 & 20,363 & 16.8 \\
1998 & 3,782 & 25,707 & 21,430 & 16.6 \\
1999 & 3,680 & 26,364 & 21,648 & 17.9 \\
2000 & 4,077 & 29,124 & 23,849 & 18.1 \\
2001 & 3,656 & 31,668 & 25,090 & 20.8 \\
2002 & 9,813 & 30,166 & 24,295 & 19.5 \\
2003 & 10,906 & 32,281 & 25,670 & 20.5 \\
2004 & 12,748 & 36,196 & 28,377 & 21.6 \\
2005 & 14,459 & 40,312 & 31,124 & 22.8 \\
2006 & 14,204 & 44,184 & 33,338 & 24.5 \\
2007 & 15,260 & 49,061 & 35,862 & 26.9 \\
\hline
\end{tabular}

Source: CHUS data, 1988-2007. 
of urban household saving increased from 5.6 percent in 1988 to 26.9 percent in 2007. These trends are generally consistent with the documented rise in household saving based on aggregate data.

\subsubsection{Household Saving by Region and Income Level}

Figure 5.7 shows that the Chinese household saving is positively related to household incomes. More specifically, the four lines in the graph indicate the saving rates of four income groups defined by their income quantiles. The saving rates of the lowest income group ( 0 to 25 percent) fluctuated between 5 and 10 percent in most years, ending at 7 percent in 2007 . In contrast, the saving rate of the highest income quantile (75 to 100 percent) began at 10 percent in 1988 and increased steadily and rapidly to above 34 percent in 2007, a level that is 27 percentage points higher than that of the lowest income group in that year. This pattern of higher saving among richer families appears to be consistent with the observations in developed economies (e.g., Dynan, Skinner, and Zeldes 2004). Therefore, for China, the rise in household saving appears to be related to the growing income inequality during the process of economic transition. These patterns imply that income transfers from the rich to the poor can raise the propensity to consume in China today. We will revisit this point when discussing the effects of proposed government policies on household saving in the concluding section of this chapter.

Saving rates by region are presented in figure 5.8, where we take a threeyear moving average saving rate for each region to mitigate fluctuations in

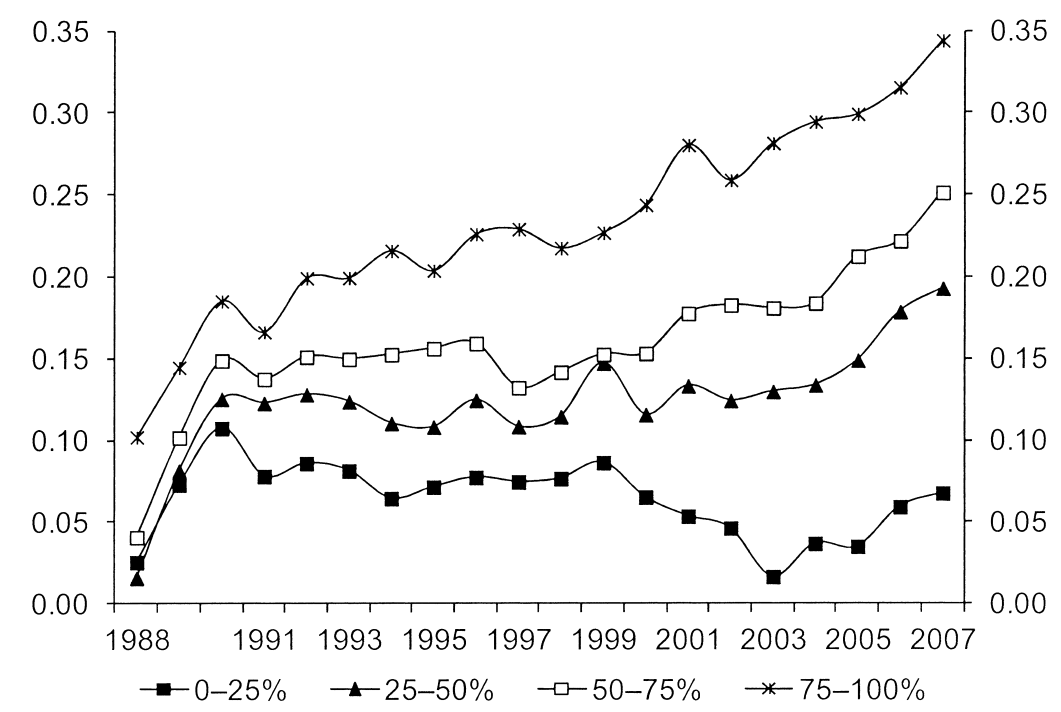

Fig. 5.7 Saving rates by income levels, 1988-2007

Source: UHS data, 1988-2007. 


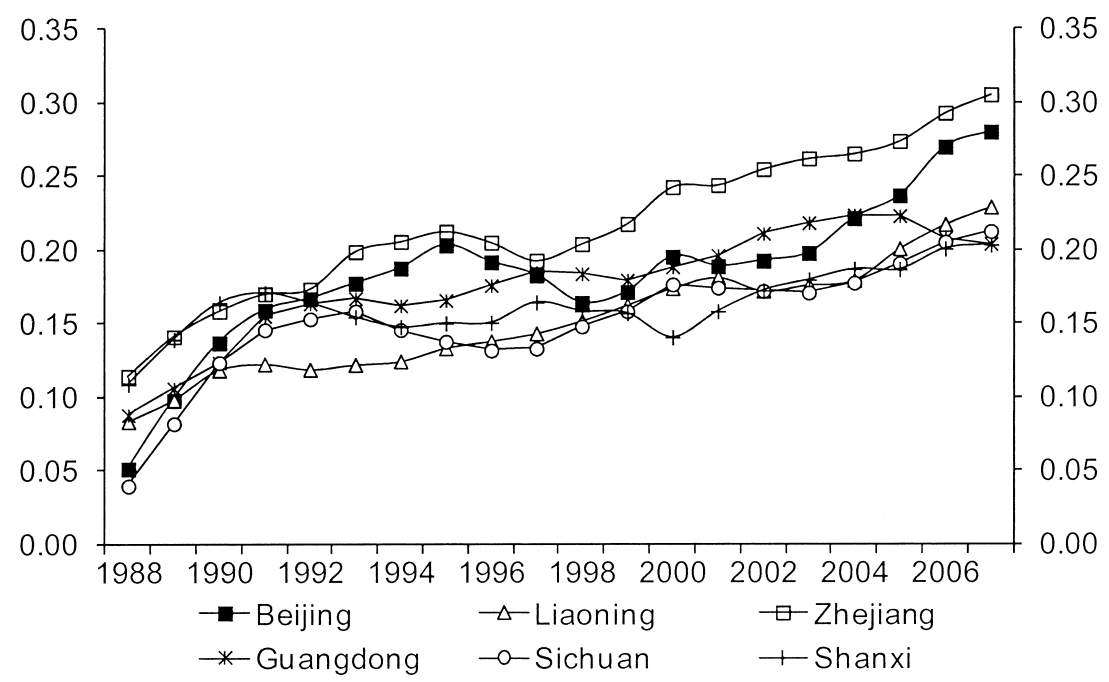

Fig. 5.8 Three-year moving average saving rates by region, 1988-2007

Source: UHS data, 1988-2007.

the measure because of the small size of the sample. The figure reveals that richer provinces, such as Zhejiang and Beijing, have much higher average saving rates than the poor provinces of Liaoning, Sichuan, and Shannxi. The gap in saving rate was initially small in the late 1980s and early 1990s but grew significantly to about 10 percentage points across regions in 2007. Overall, these patterns are consistent with the documented saving rates by income.

\subsubsection{Demographic Structures and Life Cycle Saving Profiles}

Household saving decisions are pertinently related to their demographic structures. As revealed in table 5.4, family structures in urban China experienced substantial changes in the past two decades. The average size of the household dropped from 3.5 in 1988 to 2.9 in $2007,{ }^{10}$ whereas the average age of the household head increased from 43.2 to 47.3 , suggesting the advent of an aging society. The most striking pattern in the table is the sharp decline in child dependency, which is defined as the percentage of households with children below sixteen, from 68 percent in 1988 to 37 percent in 2007. The decline in child dependency is an outcome of the strict implementation of China's one-child policy that began in earnest in 1979.

We plot the saving rates for households of different demographic struc-

10. A household is defined as a residential unit where family members live and have meals together for an extended period of time during the year of the survey. Therefore, family members who live outside the residential unit are not counted as members of a household. 
Demographic structures of the household, 1988-2007

\begin{tabular}{cccccc}
\hline Year & $\begin{array}{c}\text { Household } \\
\text { size }\end{array}$ & $\begin{array}{c}\text { Age of } \\
\text { household } \\
\text { head }\end{array}$ & $\begin{array}{c}\text { Schooling of } \\
\text { household } \\
\text { head }\end{array}$ & $\begin{array}{c}\text { Child } \\
\text { dependence } \\
\text { ratio }\end{array}$ & $\begin{array}{c}\text { Old } \\
\text { dependence } \\
\text { ratio }\end{array}$ \\
\hline 1988 & 3.5 & 43.2 & 10.1 & 0.68 & 0.11 \\
1989 & 3.5 & 43.8 & 10.3 & 0.66 & 0.12 \\
1990 & 3.4 & 44.5 & 10.3 & 0.63 & 0.11 \\
1991 & 3.3 & 43.9 & 10.6 & 0.64 & 0.10 \\
1992 & 3.3 & 44.7 & 10.9 & 0.62 & 0.10 \\
1993 & 3.2 & 45.2 & 10.9 & 0.60 & 0.10 \\
1994 & 3.2 & 45.7 & 11.0 & 0.58 & 0.12 \\
1995 & 3.2 & 45.5 & 11.1 & 0.57 & 0.12 \\
1996 & 3.2 & 46.1 & 11.2 & 0.54 & 0.12 \\
1997 & 3.2 & 45.7 & 11.2 & 0.53 & 0.12 \\
1998 & 3.2 & 46.0 & 11.3 & 0.50 & 0.13 \\
1999 & 3.1 & 46.4 & 11.3 & 0.47 & 0.12 \\
2000 & 3.1 & 47.2 & 11.4 & 0.44 & 0.14 \\
2001 & 3.1 & 47.3 & 11.4 & 0.43 & 0.13 \\
2002 & 3.0 & 47.9 & 11.4 & 0.39 & 0.12 \\
2003 & 3.0 & 47.8 & 11.5 & 0.38 & 0.11 \\
2004 & 2.9 & 48.2 & 11.6 & 0.35 & 0.12 \\
2005 & 2.9 & 48.2 & 11.6 & 0.36 & 0.13 \\
2006 & 2.9 & 48.3 & 11.7 & 0.34 & 0.12 \\
2007 & 2.9 & 47.3 & 11.9 & 0.37 & 0.11 \\
\hline
\end{tabular}

Source: CHUS data, 1988-2007.

tures in figure 5.9. Persistent increases in saving rates are shown across different types of households, rising by about 21 percentage points in the twenty-year period on average. Since the late 1990s, households with elderly experienced faster growth in saving than the whole sample. Later on, we will discuss that this trend is consistent with the decline in pension incomes for the retired; thus, families with elderly tend to save more to insure smooth consumption. In contrast, households with children tend to save less. This observation is consistent with the fact that costs of children have risen rapidly in recent years. Therefore, for households with middle-aged heads, the increase in their expenditures on raising children appears to have more than offset their higher earnings, thus dragging down their household saving relative to those of other households.

Figure 5.10 presents the age-saving profiles by age of the household head for the periods of 1988 to 1990 and 2005 to 2007. These profiles are perhaps the most important empirical patterns we have documented for the household sector that shed light on the changes in their saving over the two decades. As some age cells contain limited number of observations, we deploy threeage and three-year moving average saving rates to smooth the data series. The 1988 to 1990 age-saving profile reveals a relatively flat "hump-shape," which resembles the typical life cycle saving profiles observed in other econo- 


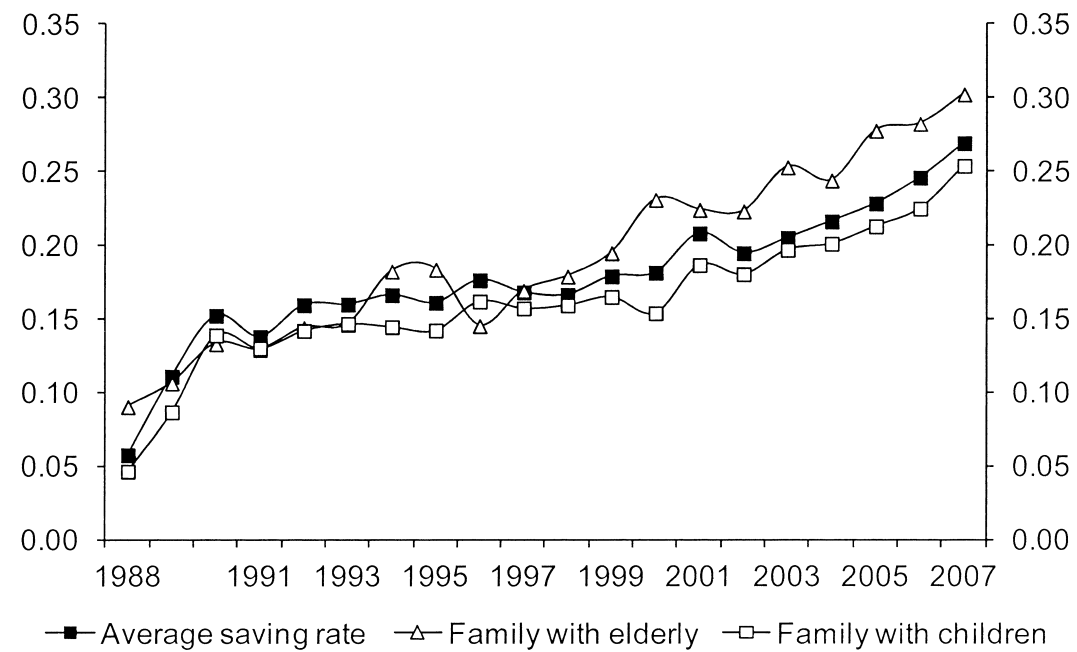

Fig. 5.9 Household saving rates and demographic structure, 1988-2007 Source: UHS data, 1988-2007.

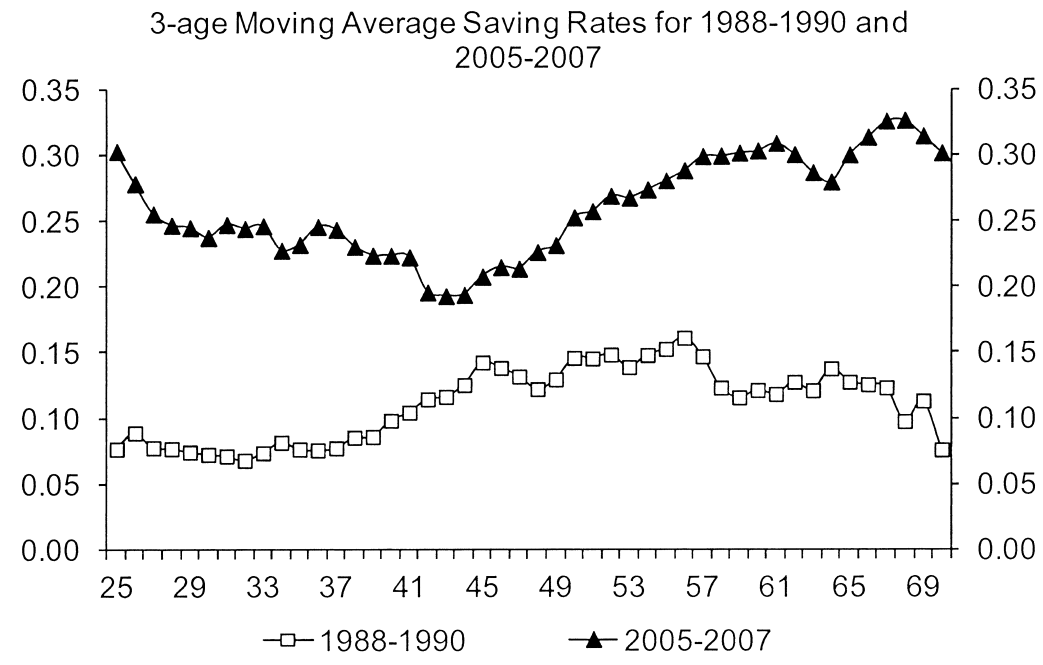

Fig. 5.10 Age saving profiles by age of household head Source: UHS data, 1988-2007.

mies (e.g., Modigliani 1970). However, the saving profile for 2007 exhibits a dramatic change: (a) saving rates for households of all ages increased substantially, and (b) the profile turns into a "U-shape" over the life cycle; that is, the young and the old saved relatively more than the middle aged. These patterns are consistent with the observations made by Chamon and Prasad (2010) for selected Chinese provinces in the period of 1995 to 2005 
and those documented in Song and Yang (2010) and Ge, Yang, and Zhang (2011) using the national sample of UHS data covering the period 1992 to 2007. The two features of increasing household saving and the U-shaped age-earning profiles present a challenge for understanding the determination of household saving in China.

\subsubsection{Understanding China's High Household Saving}

Given the size of the Chinese economy and the importance of the household sector, considerable research has been devoted to understanding family saving decisions. A number of early studies applied classical models of saving, which originated from the studies of saving behavior in the developed market economies, to the case of China. Among the well-known models are the Keynesian absolute-income hypothesis, Modigliani-Brumberg's life cycle theory, and Friedman's permanent-income hypothesis. These studies, including Chow (1985), Qian (1988), Wang (1995), and Modigliani and Cao (2004), tested alternative hypotheses but ended with inconclusive findings for the saving behavior of the Chinese. One challenging fact that hardly reconciles with theory is that, instead of consuming more to smoothen lifetime consumption, Chinese households continued to save more in anticipation of higher future incomes. Moreover, the age-saving profiles of Chinese households gradually turned into a U-shaped pattern (figure 5.10), which is inconsistent with the hump-shaped profile implied by the life cycle hypothesis.

Habit formation is an alternative theory that can explain the rise in household saving during a period of rapid income growth (Carroll and Weil 1994). The notion of consumption inertia is related to a culture-based explanation to saving behavior. As the Chinese are known to be thrifty, their consumption growth could have lagged behind their income growth during the reform period, thus leading to higher household saving. This argument is supported by the empirical finding that provincial-level variations in household saving over time and space are influenced by the lagged saving rates, a result consistent with the existence of inertia or persistence (Horioka and Wan 2007). However, the empirical evidence is inconclusive. As Modigliani and Cao (2004) argue, the traditional and commonsensical explanation (e.g., why Chinese households are thrifty) counts little, if at all. Indeed, from the 1950 s to the mid-1970s, household saving rates in China were below 5 percent, and the sudden spurt occurred during the reform period. Studies based on household data also could not find evidence showing that the current consumption growth is positively correlated with the past consumption growth (Chamon and Prasad 2010). Given that older cohorts usually carry more cultural tradition than younger cohorts, Zhou (2007) rejects the thrifty factor as an important determinant of Chinese household saving. Using the 1988 to 2003 China Health and Nutrition Surveys, he finds that younger Chinese cohorts actually have a higher propensity to save than older cohorts after controlling for other saving determinants. 
Demographic changes induced by China's population-control policies could have an effect on household saving through two channels. First, as the nonworking population consisting of the young and the old consumes without producing an income, a rise in their share in the population tends to reduce national household saving. Second, in a developing country without a mature social security system, children often provide old-age support to their parents, and thus children act as an effective substitute for life cycle saving. Motivated by these factors, Modigliani and Cao (2004) use the ratio of employed population to the number of minors up to age fifteen to approximate demographic change. They find that the decline in the young population dependency for the period of 1953 to 2000 increased Chinese household saving through both effects of "less mouths to feed" and old-age security. However, this time-series evidence is not confirmed by panel data studies. Neither aggregate dependency ratio (e.g., Kraay 2000) nor separate accounts of the young and the old dependency ratios (Horioka and Wan 2007) are found to have a significant effect on the household saving rates across Chinese provinces. Applying cohort analysis to data from the UHS, Chamon and Prasad (2010) reach a similar conclusion that demographic structural shifts do not go very far in explaining saving behavior in China.

Competitive saving motive is yet another demographic factor related to the imbalanced sex ratio in China (Wei and Zhang 2011). As the two authors argue, the traditional preference for a son is widespread in China. With restrictive population control policies, many families use the inexpensive type-B ultrasonic technology to detect the gender of fetuses and engage in sex-selective abortion, leading to a severe imbalance in the sex ratio. The intensified competition among men for potential wives stimulates households with a son to spend thriftily to accumulate wealth in order to gain a competitive edge in the marriage market. Building on this idea, Wei and Zhang use provincial panel data (1978 to 2006) to test the effect of sex ratio imbalance on household saving. They show that the imbalanced sex ratio significantly increases household savings, with approximately 68 percent of the increase in rural saving rate and 18 percent of that in the urban rate being attributed to the rise in the sex ratio.

Economic transitions in China not only involved a decline in the size of the state sector but also made a transition from public provision of education, health care, and housing services to private expenditures on these lumpy purchases. The uncertainty associated with the transition could trigger precautionary motives to save. In particular, by the mid-1990s, the Chinese government realized that its gradualist reform policy could no longer manage the mounting losses of SOEs and decided to take more aggressive steps, first allowing the privatization of small and medium SOEs and then, beginning in 1997, moving forward with more aggressive restructuring. The objective was to shut down losing SOEs, establish modern forms of corporate governance, and delink the provision of social services from 
individual employers. This would be accomplished through the privatization of housing and the shifting of the federal responsibility of health insurance, unemployment insurance, and pension provisions to the local governments, employers, and employees themselves. These aggressive reforms led to mass layoffs in SOEs. From 1996 to 2002, about 32 million workers were laid off from the state sector. Based on the 2001 China Urban Labor Survey and the 2000 Population Census, Giles, Park, and Zhang (2005) estimate that the unemployment rate of urban permanent residents increased from 6.1 percent in 1996 to 11.1 percent in 2002. Using independent population data sources, Knight and Xue (2006) arrive at almost similar estimates, showing that China's urban unemployment rate increased gradually from 7.7 percent in 1995 to 11.5 percent in 2000 .

Given the earnings uncertainty and unemployment risk combined with liquidity constraints and incomplete unemployment insurance, Chinese urban households that experienced past income uncertainty appeared to have increased their propensity to save in the period of 1995 to 1999 (Meng 2003). Moreover, the predicted probability of displacement had an even stronger effect on saving for households without unemployed members. Although these findings are robust for the household sample drawn from the specific period, reconciling the findings with the macroeconomic facts is difficult. The reason is that, when the employment uncertainty associated with state-sector restructuring continued to rise and reached its peak in the late 1990s, household saving rate did not increase accordingly but rather fluctuated within a narrow range of 16.2 to 18.1 percent during the second half of the 1990s (table 5.3). Therefore, the precautionary saving motive stemming from employment uncertainty does not seem to explain well the surge in household saving since 2000.

Accompanied with the state sector reforms, budget allocations for education, health care, and housing services declined substantially. For instance, expenditures on health and education only accounted for 2 percent of household consumptions in 1995, but this share rose to 14 percent by 2005 . Chamon and Prasad (2010) argue that these rising private financial burdens could induce higher household saving, as younger families accumulate assets for future education spending, older families prepare for uncertain health expenditures, and most people save to prepare for mortgage payments or housing upgrades. Although these are plausible factors, their quantitative effects on savings are difficult to assess. Conceptually, as most of the young adults have already finished their own education, there is no need to save for that purpose; they might have incentives to accumulate assets for their children's education. However, the increase in their saving could be offset by the reduced saving of older families who have to incur higher education costs for their children who are already in school. Similar compositional effects exist for health care and housing expenditures, as higher costs tend to reduce the saving rates of those households that incur higher expenditures 
in specific years. So far, existing studies have not yet systematically assessed the combined effects on saving across different population groups.

The changes in age-saving profiles between the periods of 1988 to 1990 and 2005 to 2007 shown in figure 5.10 reveal several key features of the saving behavior of the Chinese households. A successful model that resolves the Chinese household saving puzzle should explain not only the rise in household saving but also the U-shaped age-saving profiles over the life cycle in recent years. Two recent studies, Song and Yang (2010), and Ge, Yang, and Zhang (2011), are particularly motivated to explain the stylized patterns of Chinese household savings as shown in figure 5.10. Using the comprehensive data from Chinese UHS covering the period of 1992 to 2007, Song and Yang document three dramatic changes in the life cycle earnings in China's fast-growing environment that are new to the existing literature: (a) there are large upward shifts in the earnings of successive younger worker cohorts, (b) individual age-earning profiles have become flattened during the past two decades, and (c) the aggregate pension replacement rate, which is defined as the ratio of average pension per retiree to average wages per worker in specific years, declined from about 80 percent in the early 1990 s to a range of 52 to 58 percent in 2007. Incorporating these features of the Chinese economy into a dynamic optimization model of heterogeneous agents, they show that an otherwise standard intertemporal choice model can account well for the recent surge in household saving as well as the U-shaped agesaving profiles over the life cycle.

Ge, Yang, and Zhang (2011) emphasize the interplay between China's population control policies and saving behavior based on an overlapping generation model. They find that, among several intergenerational linkages, reduced fertility resulting from the implementation of the one-child policy contributed significantly to the recent rise in household saving. Their arguments, complementing the findings of Song and Yang (2010), help explain several special features of household saving in China.

\subsection{Prospects of China's High National Saving}

The high and rising national saving is a critical component of China's macroeconomic imbalances and is believed by some to be an important contributor to the global saving glut. Indeed, the high aggregate saving rate of about 50 percent of the GDP in recent years not only surpassed the peak saving levels of Japan, Korea, and other East Asian economies during the years of their miracle growth rates, but also has been the highest in the world among economies of significant size. This remarkably high national saving has supported China's high-investment, export-led growth model. As national saving has exceeded the total investment in recent years, and exports have exceeded imports, China's large current account surplus has become an important part of the global imbalances. We show in this chapter that 
corporate, household, and government sectors have all contributed significantly to the upsurge in national saving in the past decade. The key causes include China's fast economic growth, accession to the WTO accession, rising corporate profits, changes in life cycle earnings, pension system, other provisions of social services, and the demographic transition.

In the aftermath of the global financial crisis, the Chinese economy is facing a series of challenges; responses to these challenges will likely evolve into systematic structural adjustments. After more than a decade of heavy public investments in basic infrastructure, the diminishing returns on similar projects will likely set in, and due to external pressure, China is likely to experience relatively moderate export growth in the future and has no choice but to pursue a more balanced current account. These broad projections imply that China will have to rely increasingly on vigorous domestic demands to assure sustained growth, structurally reforming the previous high-investment, export-led growth strategy. Hence, the transition from a high-saving to a high-consumption regime will be at the center of public attention and policy.

Based on the previous analysis of saving determinants and imminent macroeconomic, demographic, and policy trends into the future, we assert that the Chinese national saving may have already peaked at around 2007. A main reason behind this judgment is the likely slowdown in China's future growth, which is projected at an average annual rate of 8.1 percent for 2011 to 2015 by the World Bank (World Bank 2010a) and an even lower range of 5.37 to 7.27 percent for 2010 to 2020 by the Asian Development Bank (Lee and Hong 2010). The national saving is positively correlated with economic growth (e.g., Carroll and Summers 1991; Deaton and Paxson 2000). Using 2.52 as the growth elasticity of national saving for China for 1978 to 2000 (Modigliani and Cao 2004), the decline in average GDP growth from 9.8 percent in the past decade to 8.1 percent as forecast by the World Bank for the next five years would reduce China's aggregate saving rate by about 4.3 percentage points. Our previous analysis is suggestive of the channels of the effect. Slower GDP growth will mean reduced growth in value-added production tax and reduced income tax for the government, and therefore a lower saving rate if the government's consumption growth is held stable. Our foregoing analysis of corporate earnings suggests that slower GDP growth will also imply reduced capacity for corporate saving.

The corporate sector will likely have a lower saving/GDP ratio in the foreseeable future because of the gradual decline over time in China's gains resulting from its accession to the WTO, the initiation of dividend payments for the state sector, and the pending increase in labor costs. As the largest shareholder, the state did not require SOEs to pay dividends in the past. However, with rising profits after the state-sector restructuring in the late 1990s, the Chinese government started to require dividend payments in 2008. This policy could squeeze corporate saving. 
Moreover, reports of labor unrest in China are increasing, including news on labor strikes in Toyota and Honda joint-venture plants and the string of worker suicides at the Foxconn facilities in early 2010. Sentiments favoring the protection of the rights of workers have grown in China as revealed by both media and government sources. By July 2010, eighteen provinces had announced increases in minimum wages by an average of 20 percent. Nationwide increases in the minimum wage will likely spread to nine more provinces by the end of the year. Given the decline in the share of labor income in the GDP (figure 5.4), there have been reports that the Chinese government plans to raise the wages of production workers systematically as a way to boost domestic production and move the economy away from the reliance on exports for growth (Ho 2010). The National Development and Reform Commission, which formulates and coordinates national economic policies, have been developing an income redistribution reform plan that is likely to be incorporated into the twelfth five-year plan for the period of 2011 to 2015. Although we do not intend to analyze the efficiency loss and welfare consequences of implementing such policies, transferring income from high-income to low-income groups under Chinese conditions, ceteris paribus, may indeed lower the average household saving rate because lowincome families have higher propensity to consume (figure 5.7). In addition, higher labor costs may suppress the profits of enterprises, thus reducing the capacity of corporate entities to save.

Other evolving forces are also likely to reduce household saving in the foreseeable future. The inevitable slowdown in the growth of labor earnings will likely occur across all age groups in conjunction with a gradual steepening of age-earning profiles, a reversal of what is observed during the period of extraordinary income growth (Song and Yang 2010). Over time, the life cycle earnings in China will converge gradually to the typical earnings profiles observed in more advanced economies. The combined effects of slower earnings growth and the steepening of age-earnings profiles will reduce household saving. As Song and Yang point out, the existing pension contributions under the three-pillared system have fallen far behind the targeted levels. However, in the coming years, the pension system is likely to be improved to meet the targeted provisions better. A more robust retirement system will lead to two consequences. First, with a higher level of pension replacement and thus less retirement risk, individuals will have less pressure to save during their working time. Second, a more complete implementation of the three-pillared pension system will gradually raise the contribution of employers from the current 5 percent of average wages to the policy target of 17 percent wage taxes. This change will again reduce the capacity of enterprises to save.

Population aging in the next several decades will have an effect on aggregate saving as well. According to projections made by the United Nations Population Council, China's dependency ratio, which is defined as the 


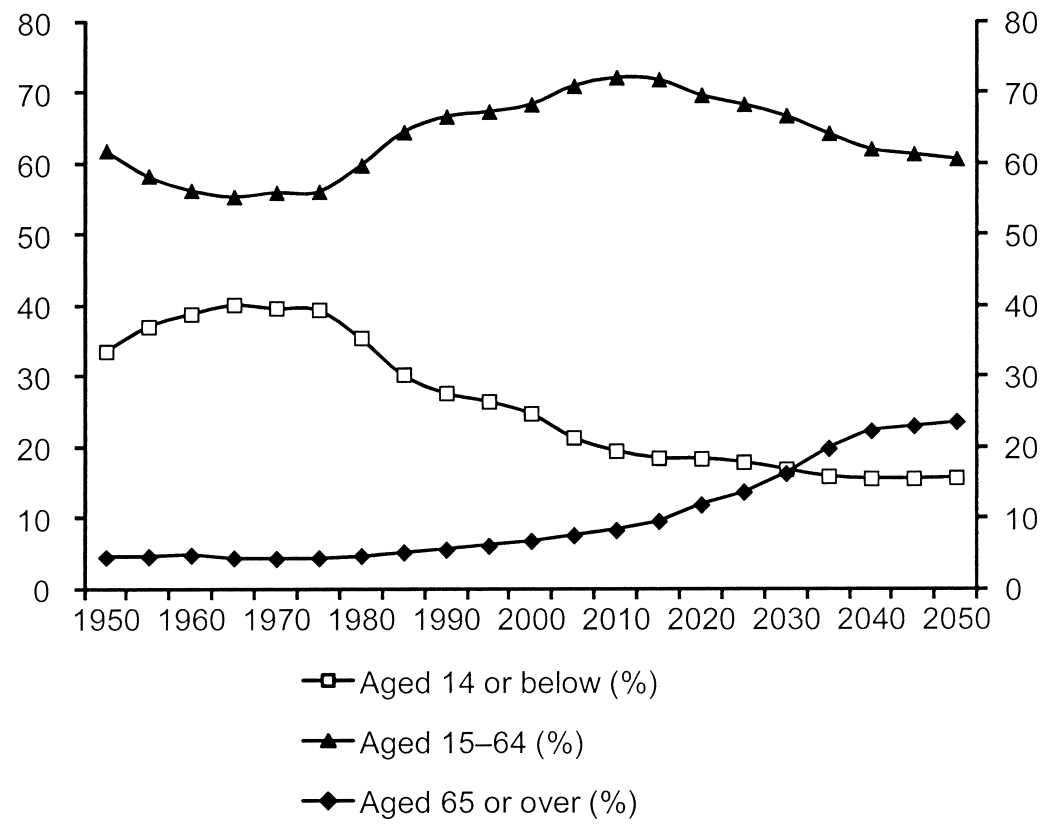

Fig. 5.11 China's long-term population trends (percentage): 1950-2050

Source: United Nations (2009).

sum of the young aged fourteen or below and the old aged sixty-five or above divided by the working population aged between fifteen and sixty-four, has reached the lowest level at 38.5 percent in 2010 (figure 5.11). However, this ratio will rise dramatically to 64.7 percent in 2050 , a level comparable to the US figure of 67.7 percent in that year. What drives this rising trend is age dependency: the percentage of population aged sixty-five or above will increase from the current 11.5 percent to an astounding 38.9 percent in 2050, a level higher than that of Japan (37.8 percent) and the United States (21.6 percent) projected for that year. Rising dependency ratio, especially for the old, will likely reduce aggregate household saving through not only the more mouths to feed effects but also the fact that old dependency is generally associated with lower personal saving in high-income economies. This demographic trend has already set in to influence saving, labor markets, and other aspects of the Chinese economy.

The reasons behind the high and rising national saving in China in the last decade are complex. Our medium-term outlook suggests a declining trend in Chinese saving that will help facilitate the transition from an investmentdriven growth model to a growth paradigm that increasingly relies on the role of domestic consumption. Radical policy interventions that aim to stimulate consumption, such as the proposed dramatic increases in minimum 
wage and income-doubling plan for production workers in five years, would involve some risk. Our view is that reliance on the momentum of market and demographic forces, when combined with policies such as building a robust social security system, can help China achieve a successful transition toward a more balanced growth.

\section{References}

Bai, Chong-En, Jiangyong Lu, and Zhigang Tao. 2009. "How Does Privatization Work in China?" Journal of Comparative Economics 37 (3): 453-70.

Bahl, Roy W. 1999. Fiscal Policy in China: Taxation and Inter-governmental Fiscal Relations. South San Francisco: The 1990 Institute, University of Michigan Press.

Carroll, Christopher D., and Lawrence H. Summers. 1991. "Consumption Growth Parallels Income Growth: Some New Evidence." In National Saving and Economic Performance, edited by B. D. Bernheim and J. B. Shoven, 305-48. Chicago: University of Chicago Press.

Carroll, Christopher D., and David N. Weil. 1994. "Saving and Growth: A Reinterpretation." Carnegie-Rochester Conference Series on Public Policy 40:133-92.

Chamon, Marcos D., and Eswar S. Prasad. 2010. "Why Are Saving Rates of Urban Households in China Rising?" American Economic Journal: Macroeconomics 2 (1): 93-130.

Chow, Gregory. 1985. "A Model of Chinese National Income Determination." Journal of Political Economy 93 (4): 782-92.

Deaton, A., and Christina H. Paxson. 2000. "Growth, Demographic Structure, and National Saving in Taiwan." Population and Development Review 26 (Supplement): $141-73$.

Dynan, Karen E., Jonathan Skinner, and Stephen P. Zeldes. 2004. "Do the Rich Save More?" Journal of Political Economy 112 (2): 397-444.

Ferri, Giovanni, and Li-Gang Liu. 2009. "Honor Thy Creditors Beforan Thy Shareholders: Are the Profits of Chinese State-Owned Enterprises Real?" The Hong Kong Institute for Monetary Research (HKIMR) Working Paper no. 16.

Ge, Suqin, Dennis Tao Yang, and Junsen Zhang. 2011. "Population Control Policies and the Chinese Household Saving Puzzle: A Cohort Analysis." Working Paper. The Chinese University of Hong Kong.

Giles, John, Albert Park, and Juwei Zhang. 2005. "What Is China's True Unemployment Rate?" China Economic Review 16:149-70.

He, Xinhua, and Yongfu Cao. 2007. "Understanding High Saving Rates in China." China and World Economy 15 (1): 1-13.

Ho, Chua K. 2010. "Salary Gains to Damp Capital Spending." China Daily, June 8. Hofman, Bert, and Louis Kuijs. 2006. "Profits Drive China’s Boom." Far Eastern Economic Review 169 (8): 39-43.

Horioka, Charles Yuji, and Junmin Wan. 2007. "The Determinants of Household Saving in China: A Dynamic Panel Analysis of Provincial Data." Journal of Money, Credit and Banking 39 (8): 2077-96.

Jefferson, Gary, and Jian Su. 2006. "Privatization and Restructuring in China: Evidence from Shareholding Ownership, 1995-2001." Journal of Comparative Economics 34 (1): 146-66. 
Knight, John, and Jinjun Xue. 2006. "How High is Urban Unemployment in China?" Journal of Chinese Economic and Business Studies 4 (2): 91-107.

Kraay, Aart. 2000. "Household Saving in China." World Bank Economic Review 14 (3): $545-70$.

Kuijs, Louis. 2005. "Investment and Saving in China." World Bank Policy Research Working Paper no. 3633.

2006. "How Will China’s Saving-Investment Balance Evolve?” World Bank Policy Research Working Paper no. 3958.

Lee, Jong-Wha, and Kiseok Hong. 2010. "Economic Growth in Asia: Determinants and Prospects." Paper presented at Finalization Workshop: Long-Term Projections of Asian GDP and Trade, the Chinese University of Hong Kong, July 8-9.

Ma, Guonan, and Yi Wang. 2010. "China's High Saving Rate: Myth and Reality." Bank for International Settlements (BIS) Working Papers no. 312.

Meng, Xin. 2003. "Unemployment, Consumption Smoothing, and Precautionary Saving in Urban China." Journal of Comparative Economics 31 (3): 465-85.

Meng, Xin, Chris Manning, Shi Li, and Tadjuddin Noer Effendi. 2010. The Great Migration: Rural-Urban Migration in China and Indonesia. Northampton: Edward Elgar Publishing.

Modigliani, Franco. 1970. "The Life Cycle Hypothesis of Saving and Intercountry Differences in the Saving Ratio.” In Induction, Growth and Trade, edited by W. A. Eltis, M. F. Scott, and J. N. Wolfe, 197-225. Oxford: Clarendon Press.

Modigliani, Franco, and Shi Larry Cao. 2004. "The Chinese Saving Puzzle and the Life-Cycle Hypothesis." Journal of Economic Literature 42 (1): 145-70.

National Bureau of Statistics of China (NBS). Various years. China Statistical Yearbook. Beijing: China Statistics Press.

Qian, Yingyi. 1988. "Urban and Rural Household Saving in China.” International Monetary Fund Staff Papers 35 (4): 592-627.

Song, Zheng Michael, and Dennis Tao Yang. 2010. "Life Cycle Earnings and Saving in a Fast-Growing Economy." Working Paper. The Chinese University of Hong Kong.

United Nations, Population Division. 2009. World Population Prospects: The 2008 Revision Population Database, China. http://esa.un.org/unpp.

Wang, Yan. 1995. "Permanent Income and Wealth Accumulation: A Cross-Sectional Study of Chinese Urban and Rural Households." Economic Development and Cultural Change 43 (3): 522-50.

Wei, Shang-Jin, and Xiaobo Zhang. 2011. "The Competitive Saving Motive: Evidence from Rising Sex Ratios and Savings Rates in China." Journal of Political Economy 119 (3): 511-64.

Wong, Christine, and Richard Bird. 2008. "China's Fiscal System: A Work in Progress." In China's Great Economic Transformation, edited by Loren Brandt and Thomas Rawski, 429-66. Cambridge: Cambridge University Press.

World Bank. 2010a. China Quarterly Update. Beijing: World Bank Office. 2010b. World Development Indicators 2010. http://data.worldbank.org /data-catalog.

Yang, Dennis Tao, Vivian Weijia Chen, and Ryan Monarch. 2010. "Rising Wages: Has China Lost Its Global Labor Advantage?" Pacific Economic Review 15 (4): 482-504.

Zhang, Haiyan. 2008. "Corporate Governance and Dividend Policy: A Comparison of Chinese Firms Listed in Hong Kong and in the Mainland." China Economic Review 19:437-59. 
Zhou, Shaojie. 2007. "Essays on Household Consumption and Household Saving Behavior of Chinese Urban Residents." PhD diss. The Chinese University of Hong Kong.

\section{Comment Leslie Young}

\section{Introduction}

Professors Yang, Zhang, and Zhou (YZZ) provide useful insights into the question in the title of their chapter. As their work covers a lot of interesting ground in a highly professional manner, I shall not offer a detailed critique. Instead, I shall propose some alternative perspectives on their work that link China's savings rate to fundamental aspects of its modern history and political economy. Specifically, I link China's high savings rate to (a) the social capture of the rents and capital gains foregone by the landlords and capitalists expropriated after 1949, and (b) the recycling of those surpluses into investment by both private companies and state-linked companies. The capital gains on the expropriated assets were massive when China opened up its economy and revalued those assets at world prices. The recycling of the surpluses into investment was massive because China's state-linked corporations effectively have no owners, but their managers now earn both monetary and political credits from good performance. We might say that China's savings are high because of Mao Zedong, Deng Xiaoping, and the "social market economy with Chinese characteristics."

\section{Evidence from the Relative Purchasing Power of National Currencies}

A useful perspective on the "revolutionary" origins of China's high savings is provided by the well-known impact of revaluing China's GDP according to Purchasing Power Parity. China's currency stands out from competing countries in enjoying high purchasing power relative to the US\$. According to 2007 World Bank figures, 1 yuan buys in China 2.21 times what its US\$ equivalent at market exchange rates would buy in the United States. For Brazil, Mexico, and Poland, the corresponding factor is about 1.43.

So Chinese firms could pay $1.43 / 2.21=0.65$ of the salaries in these three countries, yet their workers would enjoy the same purchasing power. The Chinese firms competing with firms from these three countries could capture the difference as higher profits. Yang, Zhang, and Zhou show that profits are mostly saved, rather than being paid out as dividends.

Leslie Young is the Wei Lun Professor of Finance and executive director of the Asia-Pacific Institute of Business at the Chinese University of Hong Kong.

For acknowledgments, sources of research support, and disclosure of the author's material financial relationships, if any, please see http://www.nber.org/chapters/c12458.ack. 